\title{
Research on the Application of Communicative Approach in College English Listening and Speaking Teaching Based on Network Background
}

\author{
Shuyuan Zou ${ }^{1, a}$ \\ ${ }^{1}$ Jiangxi Science \&Technology Normal University, Jiangxi, Nanchang, 330013 \\ aemail,
}

Keywords: Network Background; College English; Listening and Speaking Teaching; Communicative Approach

\begin{abstract}
The rapid development of network technology not only provides a wealth of resources for teaching, creating a real learning environment, and make teaching management more convenient. In modern society, people's communication has become more and more frequent, which also put forward higher requirements for college English listening and speaking teaching. But at present, there are still some old teaching methods and lagging behind the teaching idea. In the face of these problems and the new requirements of English courses in colleges and universities, this paper deeply studies the application of communicative approach in college English listening and speaking teaching based on the background of the network, and tries to improve the level of English listening and speaking.
\end{abstract}

\section{Introduction}

With the development of modern society and the increasingly prosperous market economy in China, the exchanges and exchanges between China and other countries have become closer, and the communication function of foreign languages has gradually become the core purpose of foreign language teaching. English is the world's most widely used language, but also Chinese major colleges and universities to open a common foreign language. In the context of the Internet, how to make college students more effective use of English communication function, has become a college English teacher group is facing important issues. The author starts from the two aspects of spoken language and listening comprehension, and explores the application of communicative teaching method in college English listening and speaking teaching under the background of network.

\section{The Theoretical Basis of Communicative Approach}

Communicative teaching method originated in the 1970s in Europe, and in the late 90s into Chinese education sector. Communicative teaching method that the human language has the main communicative competence and language ability of these two functions. The ultimate goal of using communicative approach is to cultivate the communicative competence of college students is different from the simple "language" ability [1].

The most prominent feature of communicative pedagogy is that the structure and function of language are combined to develop communicative teaching. It is put forward in the student-centered classroom teaching, in the training of students to read and write language skills on the basis of, so that they will learn the knowledge into practice, live and use.

\section{The Application of Communication Teaching Method in Oral and Listening Teaching in the} Network Context

The Application in the Oral Teaching. In the background of the network, the essence of communicative teaching method is to regard the process of language teaching as a communication process. Through the process of communication, we can acquire language and acquire communicative ability by exchanging with others. Communicative teaching method advocates the 
language communication function as the core teaching content, as soon as possible in the real situation to start foreign language teaching, advocate the teaching process of communication, emphasizing the level of language application, In addition, the communicative approach in the emphasis on the use of communication and traditional teaching method is not contradictory, in the course of the use of appropriate words, grammar and translation teaching, so as to accumulate knowledge for language communication and lay a solid foundation.

In the context of the network, in order to be able to improve students' language skills as soon as possible, in the use of communicative approach in the process must strictly follow the following four principles. The first is the principle of student-centered, teachers are the guide of the course, but must not ignore the core of the status of student teaching activities; followed by the principle of communication, the real communication scenarios will make learning to a higher level; again is the principle of the task, Through the language of communication to complete the task of learning; Finally, the principle of meaning, if the content of teaching can have meaning to the learners, then the learning effect will be significantly improved. So that students into the curriculum activities, and thus promote their own language level.

The Application in the Listening Teaching. In the pre-listening session, in advance let the student understand the specific meaning of certain words, and make some vivid multimedia courseware to show the background knowledge, so as to deal with students may appear language and knowledge problems. Introduce the background of listening materials in the form of animation to enhance students' interest in learning and learning initiative. When playing the recording, the students begin to listen carefully. The most common classroom activity in this session is to answer questions. In the process of communication with students, the most critical thing is to give students a positive and encouragement, because students are difficult to immediately give the correct answer. At the same time, teachers should also give students full of discourse, discussion and hearing materials related topics. Teachers can also play some foreign video, so that students engage in dialogue training or role performances. College students can choose the method of interest, which can effectively stimulate the enthusiasm of learning. In addition to oral practice, but also through the hearing material layout of some short essay writing and dictation training, in the consolidation of students on the basis of listening materials to understand the level of students to enhance the level of writing [2].

\section{The Strategies of Communicative Teaching Method Applied to College English Listening and Speaking Teaching in the Network Context}

Any kind of teaching method there are advantages and disadvantages, communicative approach is no exception. In the context of the network, the majority of English teachers should be "whichever is the essence, to its dregs", give full play to the advantages of communicative approach, abandon its shortcomings, by virtue of the existing network resources and teaching methods, so that the teaching method in the use of In the process as much as possible to play the best results.

Strengthen the Introduction of English-Speaking Countries. There are rich and varied historical and cultural backgrounds in various languages. There are also differences in the customs and lifestyles of different ethnic groups. Therefore, the culture has the characteristics of nationality. The ultimate goal of learning English is to communicate with people who have different cultural backgrounds. Therefore, in the teaching and learning of college English, in addition to the basic language teaching, it is necessary to transfer knowledge from the cultural point of view. In the actual teaching process, teachers should consciously and systematically improve the introduction of cultural background knowledge cannot ignore the appropriateness of communicative language. In the context of the network, teachers can through the multimedia courseware, animation, PPT and other forms to the students to teach the original ecology of English and culture, to guide students to learn authentic expression and language skills and students awareness of cross-cultural communication.

Strengthen the Summary of Comments. After each use of communicative approach to the implementation of listening and speaking classroom communication activities, teachers should try 
to make a systematic summary of the specific situation and a short-term evaluation. In the process of summarizing, you can summarize the students' speeches, summarize them and make some constructive comments to supplement the deficiencies. In the short link, we need college students to speak or the wonderful performance of communication activities to encourage and the existence of the problems given correction.

In addition, teachers in the use of communicative approach in the process of both attention to language, but also cannot ignore the grammar and word teaching. If students do not have the correct grammar, they will lose logic in the process of communicating with others. Communicative pedagogy is not intended to divorce grammar teaching from the ability of communication skills and you can try to integrate the two, or according to the actual needs of students, set up a few hours of training to explain the grammar.

Enhance the Application Level of Communicative Approach of College English Teachers As Soon As Possible. At present, the quality of college English teachers in our country is different. Many teachers have a lack of systematic understanding of communicative teaching methods. In the background of the network, they still use translation method to emphasize the teaching of grammar. With the progress of Internet information technology, teachers should follow the footsteps of the times continue to learn new cultural knowledge, to explore more effective teaching strategies. The education sector of the country should also strengthen the training of teachers from time to time promote new ideas and the birth of new methods. Especially in the new classroom teaching mode of training, to encourage teachers to grasp the updated teaching methods as soon as possible to improve the quality of teaching [3].

Enhance the Enthusiasm of College Students. Many students into the university campus, they gradually lost the enthusiasm and initiative of learning. University teachers and secondary school teachers, not so strict, most of the students stressed the initiative and consciousness, to cultivate students' independent thinking and their ability to deal with the problem. Coupled with the background of the network, many students began to use non-profit network for activities outside of English learning. In learning is also in a passive state. Therefore, the English teachers should take a scientific teaching methods to stimulate students' enthusiasm and initiative to learn, so that students into the communication activities, and thus achieve the purpose of enhancing the level of communication. In this sense, the use of communicative approach in the context of the network, not only can improve the students' ability to use language, but also help students change their learning philosophy, to establish a more optimistic attitude towards learning.

\section{Conclusion}

To sum up, the teaching idea of communicative teaching method covers the function of the whole language communication and the psychological needs of college students, and emphasizes the cultivation of communicative competence, which is of great significance to the teaching and learning of English in Chinese colleges and universities. In the background of the network, in order to meet the needs of modern teaching, we should rationally use the teaching of less time, combine the new teaching ideas with the traditional teaching methods, and make flexible use of the teaching and teaching design of communicative teaching method. Teachers should also be based on the actual teaching situation and the specific level of students to focus on teaching, and then to achieve the purpose of cultivating college students' communicative competence.

\section{References}

[1] Guo Ran, Zhao Shengnan, Chu Chunyan, etc . Project-based collaborative learning in college English listening and speaking teaching practice and research [J]. Value Engineering, 2015, 15 (6): 275-275,276. 
[2] Li Yang. Analysis on the Feasibility of Reversing Classroom Model in College English Listening and Speaking Teaching[J]. Journal of Jiamusi Vocational College, 2016, 12 (11): 331,333.

[3] Yu Shipeng, Wen Xiaolan. On the constructive interactive teaching model in college English listening and speaking teaching application[J]. Education sector, 2016, 20 (24): 90. 